Article

\title{
The United Nations Security Council at the Forefront of (Climate) Change? Confusion, Stalemate, Ignorance
}

\author{
Judith Nora Hardt \\ Centre Marc Bloch, Germany; E-Mail: judith.hardt@cmb.hu-berlin.de
}

Submitted: 31 May 2021 | Accepted: 29 September 2021 | Published: 22 October 2021

\begin{abstract}
In the context of the United Nations Security Council (UNSC), the debate on whether climate change should be included and how has been ongoing since 2007. This article contributes to existing research on this problem by expounding a three-fold analysis. First, it assesses the conceptual approach to the climate-security nexus from the joint statement of 10 UNSC member states in 2020. Second, it critically exposes the confusion of different climate-security conceptions and uncovers shared assumptions of the UNSC-member states in 2020 by comparing their different positions, which makes a soon-to-come agreement likely. Third, it critically evaluates whether the proposal to include climate change into the UNSC will lead to a transformative change of the institution, of the meaning of security, and on how this would correspond to the existential threats outlined in the Anthropocene context. The theoretical framework of analysis draws on critical security studies. It takes as its empirical basis the primary sources of the UNSC debate of 2020 and is also informed by the secondary literature on climate and security and the Earth System Sciences descriptions of the state of the planet.
\end{abstract}

\section{Keywords}

Anthropocene; climate change; climate-security nexus; existential threat; United Nations Security Council

\section{Issue}

This article is part of the issue "Climate Change and Security" edited by Yasuko Kameyama (National Institute for Environmental Studies, Japan) and Yukari Takamura (University of Tokyo, Japan).

(C) 2021 by the author; licensee Cogitatio (Lisbon, Portugal). This article is licensed under a Creative Commons Attribution 4.0 International License (CC BY).

\section{Introduction}

As exemplified by this thematic issue, the links between climate change and security are controversially debated, being clearly defined neither in theory nor in practice. One of the reasons for this is that many existing interpretations of the climate-security nexus confuse different aspects and provide at most a non-transparent cocktail that can appear at times as a magic potion and at others as a poison with malign effects. In theory and practice, the climate-security nexus covers a broad range of interdependent issues, such as the question of how climate change is linked to or even produces phenomena ranging from vulnerability, instability, and poverty, to loss of statehood and national territory, violent conflict, global health effects, forced displacements, and the increased intensity and frequency of weather extremes, as well as to threats to the future of humanity itself (e.g., Security Council Report, 2021; United Nations General Assembly, 2009a, 2009b, 2009c; United Nations Security Council [UNSC], 2011). Several academic propositions exist that aim to re-define the traditional security concept of the nation-state (Mearsheimer, 2001) in order to address and deal with the new quality of threat posed by climate change, and to provide guidance for global governance actors. Examples include the strengthening of the environmental dimension of human security focusing on basic human needs (Barnett \& Adger, 2007), the ecological security concept that focuses on earth system processes (McDonald, 2018), and cosmopolitan security that focuses on ethics (Burke et al., 2014). Most of this critical peace, conflict, and security research draws on Earth System Sciences descriptions, which locate the planet on a trajectory towards a "Hothouse Earth" climate (see Steffen et al., 2018). Moreover, those approaches frequently claim to offer a 
paradigm shift, which is then also applied to the necessity of redefining the very meaning and politics of security (Dalby, 2020; Hardt, 2021; Harrington \& Shearing, 2017; Lövbrand et al., 2021).

This article does not present a blueprint for how to re-define security in the new context of the Anthropocene. Instead of projecting future ideals, it takes stock of how security is understood in relation to climate change already today. For this, it takes the United Nations Security Council (UNSC) as a case study. The UNSC provides the perfect analytical object for the following reasons. First, the UNSC is the only organ with a mandate to maintain international peace and security and as such seems ideally positioned to address the enormous, multiple, and entangled threats that manifest in the climate-security nexus and the broader descriptions of "existential threat" (Lenton et al., 2019, p. 595) in the Anthropocene. Second, the fierce debate on whether and how the UNSC should or could conceive, prepare for, and handle the dramatic and varied implications of climate change has occupied the 15 UNSC (10 elected and five permanent) member states since 2007. An official recognition of the multiple connections between climate change and other larger socio-ecological phenomena, such as their links to security, is still lacking.

This article contributes to research on the UNSC case study within the climate and security literature. For this body of work, we can observe a change of tenor over the last years. In earlier research, a cautious approach to climate-security in the UNSC was called for (see e.g., Cousins, 2013; Scott, 2015) due to the possible negative consequences of militarization of environmental or climate politics and of a misuse of any environmental agenda for geopolitical interests (see e.g., Trombetta, 2008). More recently, literature has been underpinned by a growing claim that international governance actors and also the UNSC cannot continue to ignore climate change and its multiple effects and interconnections with security. Accordingly, a number of proposals for how to transform the UNSC have been put forward (Conca, 2019; Hardt \& Viehoff, 2020; Scott \& Ku, 2018). Another research focus explores ways in which climate change has already come to be included in the UNSC. Securitization (Scott \& Ku, 2018) and climatization (Maertens, 2021; Maertens \& Hardt, 2021) have served as important analytical tools that critically engage with the various UNSC debates, the informal and expertfocused Arria-Formula Meetings and the recognition of the adverse impacts of climate change on stability in several UNSC resolutions (see Security Council Report, 2021). In this development, 2020 marked an important moment in attempts to include climate change in the UNSC agenda.

This article focuses on the 2020 joint statement led by Germany, which brought together for the first time 10 UNSC member states in a Joint Initiative to Address Climate-Related Security Risks (Ten UNSC Member States, 2020). The short statement is impor- tant not only because it represents a peak in the securitization process but also because, according to several informal sources and media coverage (Dziadosz, 2020; Fillion, 2021), the German Permanent Mission (PM) had already been preparing a UNSC resolution before, but refrained from presenting it due to the announcement from the US under President Donald Trump to veto it. The 10 UNSC member states coalition statement therefore is likely to include the key points of this not publicly available draft resolution (see Security Council Report, 2021). In addition, this joint statement provides the opportunity, on the one hand, to assess how the proponents understand security in relation to climate change and, on the other, to display the effects of disentangling the climate-security cocktail. This article focuses less on process (as climatization and securitization analyses do) than on critically analyzing the conceptual approach of climate-security, which is the original and central contribution of this research because it enables a more differentiated criticism and analysis for policy makers and for scientists. The article furthermore investigates the questions of whether the UNSC stands at the forefront of including climate change and whether this would suppose a transformative change of the/for the UNSC and for security conceptions.

The analysis is based on the theoretical framework developed by critical security studies (see Bigo, 2010; Booth, 2005; Buzan et al., 1998), which share the assumption that security is a constructed concept inextricably linked to the actor itself, as well as to its historical and sociopolitical contexts, culture, and worldviews (Peoples \& Vaughan-Williams, 2010). Therefore, security is not understood as a fixed but as an evolving and context-dependent concept. Accordingly, it is used as a research tool that explores the understandings and assumptions that underpin specific threat constructions and responses as a kind of "security prism" (see Hardt, 2018). On the basis of a qualitative analysis of the primary sources, I analyze and present the climatesecurity concept by assembling the explicitly used references into referent object (security for what/whom?), threat (security from what threats?), and response (security by what means?).

The research is furthermore informed by the dispersed literature on climate and security, which focuses on different issues, such as the interrelations between climate change and violent conflict, peace (see for an overview Swain \& Öjendal, 2018) and security (see Trombetta, in press), and existential security threats (Sears, 2020). It also includes the Earth System Sciences literature and the emerging literature on international relations and security in the Anthropocene, which distinguishes between Holocene and Anthropocene thinking (Cudworth \& Hobden, 2011). While Holocene thinking presupposes a clear distinction between humans and nature, Anthropocene thinking challenges the humannature dualism and eventually implies a re-definition of the meaning of security in such a way as to overcome the 
focus on conflict in favor of a re-assessment of the central values that need to be secured in new situations of survival and ethics (see Hardt, 2018, 2021; Harrington \& Shearing, 2017).

The analysis unfolds in four sections. In the next section I assess the climate-security concept by the proponents to include climate change in the UNSC (10 UNSC member states coalition). In Section 3, this approach is juxtaposed to the descriptions of the matter submitted by the five remaining UNSC member states. I investigate whether adopting this proposal would result in a transformative change of the UNSC. The concluding section indicates some recommendations for future research, defends the assessment that a fundamental change is not in sight, and that, as a result, the security threats associated with the Anthropocene are ignored.

\section{The 10 UNSC Members States' Climate-Security Concept}

As described above, the climate-security nexus is interpreted in several different ways. Hardt and Viehoff (2020) showed that the foci and interpretations of the climatesecurity nexus varies enormously among UNSC member states and observed an important divergence between domestic and foreign politics in the UNSC context. A missing research focus so far consists in dissecting the unifying meaning/understanding of climate-security that the 10 UNSC member states coalition has in common.

In what follows, I assess this 10 UNSC member states coalition's underlying climate-security concept on the basis of two primary sources. The first is the Joint Declaration by Belgium, France, the Dominican Republic (hereafter DomRep), Estonia, Germany, Niger, Saint Vincent and the Grenadines (hereafter SVG), Tunisia, the United Kingdom (UK), and Vietnam (Ten UNSC Member States, 2020). The second is the 2020 UNSC debate "Maintenance of international peace and security: Climate and security" (UNSC, 2020). As the statements from Niger and Tunisia are missing in the official document, the Niger position is substituted by the presented brief from Niger, while the Tunisian statement is subsumed to the position of the Declaration (Ten UNSC Member States, 2020). The security prism research tool applied here enables a cross-cutting analysis of the different statements on the basis of literal quotes presented in Table 1. Though there are many differences, the aim here is to identify the, as it were, combined underlying concept that does not focus on contradictions but on grouping and making collective sense of the commonly shared descriptions. Important for this is, of course, the qualitative analysis of the empirical data and the classification into corresponding categories.

A further limitation is that this methodology neither captures the process nor future approaches but instead takes stock of how the existing underlying concept of security is influenced by and/or related to climate change. This is how I seek to analyze the cosmol- ogy/grammar that provides the background of the proponents' understanding of the climate-security concept. I also do not question whether the links between climate change and e.g., conflict exist or not, even though the academic discussion on the matter continues (see Dalby, 2020; Mach \& Kraan, 2021). Instead, I intend to capture the logics of these links that are taken for granted and described by the UNSC member states as embodied/existent. This research is limited to discourse analysis, and as such is unable to distinguish this neatly from power politics, underlying interests, or other key phenomena-indispensable notions which require future research.

In what follows, I will present the research results for the categories of security objects and goals, threats, and responses as described in Table 1 . I critically analyze how the climate-security concept that is operative in these data implies an understanding of security at variance with traditional notions. I also investigate the way in which human-nature relations are conceptualized so as to assess whether Anthropocene thinking is included in this renewed concept.

\subsection{Security Objects}

Applying the security prism as an analytical lens to these data, the detected security objects are international peace, security, and stability (Ten UNSC Member States, 2020) and "prosperity for our people and our planet" (UNSC, 2020, pp. 12 [Vietnam], 15 [UK]). Furthermore, the stability of states and societies (UNSC, 2020, pp. 5 [Niger], 14 [Estonia]) is at the center of attention. Confronting these security objects with the Anthropocene context and with the scientific descriptions of the current state of the world (Intergovernmental Panel on Climate Change [IPCC], 2021), it becomes clear that neither Life, the Earth System Boundaries, the "safe operating space" (Rockström et al., 2009), humans, children, nor future generations are included in this security understanding. Therefore, it should be emphasized that while the articulated statements on including climate change in the UNSC might at times appear to be informed by the findings of the latest climate sciences (see also other descriptions below) the referent objects of climate security remain limited to anthropocentric notions of states and societies with only the faintest emphasis on "planet" as a source of prosperity for "people."

\subsection{Security Threats}

According to traditional conceptions of security as expressed in the original UNSC mandate, the central threat to security is violent conflict. Climate change comes into the picture primarily because of its multiple adverse posited effects on conflict. In the documents, two different kinds of links between climate change and conflict appear, one indirect and one direct. Within 
Table 1. Climate-security concept of the 10 UNSC member states coalition.

\begin{tabular}{|c|c|}
\hline Security prism & Climate-Security Concept \\
\hline Security objects and goals & $\begin{array}{l}\text { - Global and international peace, security and stability of states and societies } \\
\text { - Sustainable peace and prosperity }\end{array}$ \\
\hline Security threats & $\begin{array}{l}\text { - Climate change as a threat multiplier } \\
\text { - Climate change intensifies drivers of conflict and fragility } \\
\text { - Climate change as an existential threat }\end{array}$ \\
\hline \multirow[t]{4}{*}{ Security responses } & UNSC \\
\hline & $\begin{array}{l}\text { 1. Multilateral, preventive, and responsible state action } \\
\text { 2. Improved assessments and conflict analysis } \\
\text { - Information on climate change impacts on security } \\
\text { - Local and context focused analysis of threats and responses, respecting sovereignty } \\
\text { issues and mandates } \\
\text { - Climate-related security risks inclusion into UNSC assessment and decision-making } \\
\text { - Systematic reporting on climate-related security risks by the Secretary-General } \\
\text { - Climate proofing of resolutions } \\
\text { - Climate-security approach must be sensitive to inequalities and gender } \\
\text { 3. Institutional support for the UNSC on climate-security } \\
\text { - Special Envoy and/or Special Representative } \\
\text { - Expert group }\end{array}$ \\
\hline & Other \\
\hline & $\begin{array}{l}\text { - Climate Security Mechanism } \\
\text { - Mainstreaming climate politics/proofing of the UN } \\
\text { - United Nations Framework Convention on Climate Change }\end{array}$ \\
\hline
\end{tabular}

Sources: Ten UNSC Member States (2020); UNSC (2020).

the indirect and potential relations, climate change is described as affecting certain processes, such as water and food security, displacements and social tensions (Ten UNSC Member States, 2020), sea-level rise, economic shocks, scarce resources (UNSC, 2020, p. 15 [UK]), and competition over scarce resources (UNSC, 2020, p. 12 [Vietnam]). This then leads to "potentially exacerbate, prolong or contribute to the risk of future conflicts and instability" (Ten UNSC Member States, 2020). Similarly, climate change is seen as a threat multiplier, through which, in combination with e.g., poverty and low state capacity, climate change might potentially instigate, exacerbate, prolong, and drive conflict (UNSC, 2020, p. 12 [Vietnam]).

The direct relationship between climate and conflict is expressed in the statement that climate change "intensifies important drivers of conflict and fragility" (UNSC, 2020, p. 14 [Estonia]) and aggravates existing threats (Ten UNSC Member States, 2020), in the sense of already existing conflicts, such as the case of the farmersherders conflict (UNSC, 2020, p. 6 [Niger]): "Climate change reinforces existing social, political, economic and environmental drivers of conflict" and the complexity of the effects of climate change is highlighted (UNSC, 2020, p. 10 [Belgium]). In addition, a vicious cycle between conflict and climate change is noted, given that the local and contextual situation inhibits adaptation measures to cli- mate change and is therefore in turn more prone again to conflict (UNSC, 2020, pp. 5-6 [Niger]).

The impact of climate change is understood to affect all the populations across the globe (Ten UNSC Member States, 2020), but the areas of primary concern are vulnerable regions and existing situations of conflict, such as Haiti, Afghanistan, and the Sahel (UNSC, 2020, p. 25 [SVG]). In some cases, the UNSC member states highlight their own vulnerabilities to climate change, as e.g., Niger (the Sahel), Vietnam (the Mekong), and the island states (their territorial integrity in general). The DomRep and SVG refer to their territorial vulnerability resulting from natural catastrophes and the permanent loss of land as an "existential threat" (UNSC, 2020, pp. 19 [DomRep], 25 [SVG]). This is clearly linked to the traditional and territorial understanding of security but adds new dimensions. Aside from the Small Islands Developing States and conflict-prone regions, women and girls are described as being particularly vulnerable and exposed to threats.

Other references to climate change as "our most existential challenge" (UNSC, 2020, p. 10 [Belgium]) seem to transport an additional qualitative threat dimension with respect to future generations. A more specific investigation into the ways in which this challenge is explicitly described shows, however, that the notion of future generations is absent from the climate-security concept, although young people are (partly) given a voice in the 
Belgian delegation-which aims to "not fail" their expectations (UNSC, 2020, pp. 10 [Belgium], 13 [Germany])and the Nigerien statement expresses the aim to protect young people from the impact of future conflict (UNSC, 2020, p. 6 [Niger]). This remains ignorant of the scientific descriptions of the implications of climate change (IPCC, 2021; Lenton et al., 2019) and the overall analysis shows that an existential threat for humanity and for future generations is not spelled out and therefore not of fundamental concern.

Some statements might be interpreted as alluding to a certain recognition of nature and the Earth System, but they remain the exception. Thus, the SVG statement describes the need to "drastically change our planet's trajectory" (UNSC, 2020, p. 25 [SVG]), which can be interpreted as an allusion to research on the Hothouse Earth because of the term "trajectory" (see Steffen et al., 2018). Also, Germany describes the force of nature:

As diplomats and politicians, we tend to think that everything is negotiable. This is also the underlying idea behind the Security Council: building international consensus. But we cannot negotiate with nature. The physical, chemical and geographical realities of global warming will not compromise with us....The fight against climate change should not divide us. We fight it to save ourselves, and we fight it for the people around the world who are already facing violence and displacement as a result of climate change. They cannot afford to wait. The time for diplomatic patience is therefore over. The Security Council cannot negotiate with the realities of nature. Action is all that counts. (UNSC, 2020, p. 13 [Germany])

As these quotations show, the broader context of natural forces is acknowledged to a certain degree as creating a need to act but the very notion of threat itself focuses on conflict and the stability of the state system. It is also noteworthy that the human-nature relation is perceived as separated and nature as a hostile enemy.

\subsection{Security Responses}

Looking at the category of security responses, key terms are the common responsibility (UNSC, 2020, pp. 6 [Niger], 14 [Estonia]) and multilateral action (UNSC, 2020, p. 12 [Vietnam]). Aside from these general principles, the concrete responses and activities deemed necessary are to be split up among different organizations, both within the UNSC and in other institutions outside of the UNSC. A central response within the UNSC consists in improving the conflict analysis with respect to the multifaceted impacts of the climate-security nexus (Ten UNSC Member States, 2020) and in strengthening "the capacities of the Secretariat in terms of climate expertise and coordination" (UNSC, 2020, p. 20 [France]). In order to adequately consider the perceived local and context- specific characteristic of the climate-security nexus, climate change should be included in the analysis at a local level and thereby enable to establish an "evidence-based approach to climate-security threats" and build specific "solutions to the fragile and conflict-affected States" (UNSC, 2020, p. 16 [UK]). The mainstreaming and "inclusion of climate-related security risks into the Security Council's overall assessment and decision-making" (Ten UNSC Member States, 2020), as well as the systematic reporting from the Secretary-General to the Security Council on climate-related security risks (UNSC, 2020, pp. 14 [Estonia], 16 [UK], 20 [DomRep]), are important additional responses. Furthermore, the UNSC resolutions require a general climate proofing for an effective implementation (UNSC, 2020, pp. 11 [Belgium], 16 [UK]). Meanwhile, it is emphasized that the "Council should continue with an integrated and comprehensive approach in addressing root causes of conflicts, such as poverty, injustice, militarism and disregard for international law," but adapt this list so as to also include climate change in relation to crisis and conflict (UNSC, 2020, p. 12 [Vietnam]). While a sensitive approach to inequalities and gender is claimed to be required (UNSC, 2020, pp. 5 [Niger], 15 [UK], 25 [SVG]), neither children nor future generations are explicitly mentioned, nor larger futureoriented conceptions of security or drivers of inequality. Instead, the focus lies on the local level and on the importance of respecting state sovereignty, national ownership, and mandates (UNSC, 2020, pp. 5 [Niger], 12 [Vietnam]) once decisions need to be taken on "how to build resilience" (UNSC, 2020, p. 15 [UK]). Additional measures within the UNSC consist in strengthening the institutional support for the UNSC in the form of a Special Envoy and/or Special Representative for climate-security (UNSC, 2020, pp. 13 [Germany], 14 [Estonia], 22 [France], 25 [SVG]), and in establishing an informal expert group (UNSC, 2020, pp. 10 [Belgium], 13 [Germany]).

Beyond the UNSC, a shared view of the coalition is that the UN Climate Security Mechanism (UNSC, 2020 , p. 20 [France]) needs to be bolstered further. This entity was established by a joint initiative of the United Nations Department of Political Affairs, the United Nations Environment Programme, and the United Nations Development Programme to further dialogue and exchange on the linkage between climate change and security among UN institutions, situated at the UN headquarters in New York. The UN Climate Security Mechanism also works closely with the UN Group of Friends on Climate and Security, established in 2018 by Germany and Nauru and which today counts more than 50 members (UNSC, 2020, p. 43).

Additional responses are the mainstreaming of climate policies throughout the UN and the cooperation on the issue throughout all mandates and levels of the UN (UNSC, 2020, pp. 5 [Niger], 25 [SVG]). An important disclosure is that the United Nations Framework Convention on Climate Change (UNFCCC) remains the "primary body for addressing climate 
change" (UNSC, 2020, p. 25 [SVG]), guiding "national and global responses based on mitigation, adaptation and resilience" and "contribut[ing] to the prevention of climate-induced conflicts and crises" (UNSC, 2020, p. 12 [Vietnam]).

\subsection{Cross-Cutting Critical Observations of the Security Concept}

Overall, the research results presented here correspond in several aspects to the well-known sets of traditional security, and also partly to human security, adding climate change as one of several causes of insecurity into locally specific accounts (see UNSC, 2020, p. 14 [Estonia]) and to a certain extent includes also the broader dimensions such as e.g., migration, etc. It is worth noting that the referent object and the threat description show that the major concern is conflict, while the response section shows a considerable change of position when it comes to the meaning and also the politics of security. Compared to the traditional security concept, the security responses are relatively surprising in that they do not match the above-described security object and threats. The non-militarized responses are furthermore non-extraordinary, permanent, and, as it were, preventive actions of e.g., including scientific expertise that could be interpreted as responding to the concern, frequently articulated, of a possible militarization of the issue and/or as a result of the trend of climate change riskification (see Corry, 2012; Estève, 2021). On these additional dimensions of incoherence, confusion, and the resulting tensions, more research is required. Overall, this shows that this climate security concept merges different and at times conflicting conceptual approaches and is not exhausted by existing literature.

\section{Climate Change at the UNSC: At the Forefront of Confusion, Transformation, and Ignorance}

This section extends the investigation to the remaining UNSC member states, and projects likely future developments of the UNSC with specific focus on the transformative potential resulting from a possible inclusion of climate change in the UNSC.

\subsection{At the Edge of UNSC Confusion and Consensus}

In what follows, I compare the 10 UNSC member states coalition's climate-security concept to the positions of the UNSC member states that did not sign the statement and that are portrayed as opponents/sceptics when it comes to attempts to include climate change into the UNSC, namely Russia, China, Indonesia, South Africa (hereafter S-Africa), and the US. The US is treated separately because of the special role that accrues to it due to its announcement to block the resolution and because of the relatively non-descript and non-transparent statement on the matter in the 2020 UNSC debate. The ana-
Iysis assembles the statements of the actors from the UNSC debate document (2020) in addition to the Russian and the US statements gathered from their webpages, as these are excluded from the official document. On this basis, I categorize the concerns against including climate change within the UNSC into three main clusters and I then compare the general descriptions of the climatesecurity nexus climate-security concept of Table 1 .

The assessment shows that, similar to the aboveoutlined climate-security concept, most of the remaining four states note that it is the UNFCCC that holds "the primary mandate and capabilities to galvanize that type of action by the international community" (UNSC, 2020, pp. 24 [Indonesia], 27 [S-Africa]). They argue that the different mandates, available resources, and expertise of the UNFCCC and the UNSC should not overlap (Permanent Mission of the Russian Federation to the UN [PM Russia], 2020; UNSC, 2020, pp. 17 [China], 27 [S-Africa]). Russia (PM Russia, 2020) also highlights that the UNFCCC and the Paris Agreement are the bodies in charge of climate change and that the main concern is that diverting the focus to the UNSC and pulling the "security card" will not lead to adequate responses but rather "be detrimental to those most vulnerable, in particular the least developed countries, landlocked developing countries and small island developing states." Also, Indonesia (2020, p. 24) states that "discussion and consideration regarding climate-related security risks can be beneficial only if they lead to eventual action in addressing climate change appropriately through robust mitigation and adaptation action" and thereby indirectly suggests the significance of climate policies of the UNFCCC for security. Multilateral responsible action of states is also highlighted. These descriptions are consonant with the above-described climate-security conception of the proponents.

Another shared concern, similar to the abovedescribed climate-security conception, is the missing scientific evidence on the generalized links between climate change and conflict, given that "there is no conclusive, universally recognized and scientifically substantiated evidence that climate change has an impact on armed conflicts" (PM Russia, 2020). According to S-Africa (UNSC, 2020, p. 27):

There is currently little scientific evidence to support the more generalized conclusions of a direct causality between climate change and threats to international peace and security. S-Africa therefore remains wary of introducing climate change into the Security Council as a thematic issue, or adopting generic decisions in this forum.

At the same time, S-Africa (UNSC, 2020, p. 27) states that:

Instead, where climate change is thought to be a clear contributing factor to a threat to international peace and security, it is appropriate for the Security Council 
to comment on this issue, within the specific context of the countries that may be affected.

A third unifying concern shared by all four states is that "the linkage between climate change and security risks is highly context-specific" (UNSC, 2020, p. 23 [Indonesia]) and "country-specific," and therefore needs to be addressed "in line with the mandates of the relevant resolutions" (UNSC, 2020, p. 17 [China]). Indonesia (UNSC, 2020, p. 23) states that a UNSC-climate-security approach would obscure other political factors and causes of conflict. Russia (PM Russia, 2020) outlines the complexity of the issue and of harmful effects of such a depoliticized focus on root causes of conflict as follows:

We agree that security and stability in individual countries and regions may be affected by adverse impacts of climate change as one of the multiple factors. But the root causes of conflicts are much more complex where climate change may be one of the factors, country or region specific. We strongly disagree that climate is a generic security issue. (PM Russia, 2020)

Another main concern regarding the inclusion of climate change into the UNSC is that it would "result in diverting time and resources from addressing the root causes of conflicts" and would put into doubt the different mandates of the institutions, and "dubious and vague interpretation of risk factors could only lead to false conclusions and, as a result, failure to provide effective solutions" (PM Russia, 2020). Put differently, the contextspecificity and the effects of climate change on conflict are recognized in some cases but their concept of security excludes climate other than as a contingent and local factor.

The US position requires a special assessment. The US (Permanent Mission of the US to the UN [PM US], 2020) statement does not clearly oppose including climate change into the UNSC, even though it blocked the resolution on climate change by threatening to veto it (Dziadosz, 2020; Security Council Report, 2021). Furthermore, it should be noted that during the previous Arria-Formula Meeting in April 2020, the US statement indirectly linked climate change to security, listing it as one among other factors and challenges that affects security, instability and conflict (Barkin, 2020). This incoherence and the lack of clear opposition in the written statement indicate the limitations of this assessment. In the statement, no reference to the term "conflict" can be found, but what is highlighted is the required contextspecific and local focus with reference to natural disasters: "It is this focus on work on the ground that will make a difference by continuing to enhance the resilience of our global partners to the impacts of climate change and natural disasters" (PM US, 2020). In other words, the statement does not deny potential links.

On the basis of this outline, I assemble the different descriptions and compare them to the climate- security concept of the 10 UNSC member states coalition and I find three key overlaps. The opponents do, to a certain extent, recognize several links between climate change and security. While slight variations exist between the positions of different states-the US being handled apart-an agreement can be noted on the fact that climate change in some cases is linked to conflict and the localized and contextualized approach of vulnerable and/or conflictive and/or instable local contexts and the island states impacted by climate change. The four analyzed states locate the responsibility to address the root causes in the UNFCCC and/or on the local and nationstate level, as well as stress the need for more research. The work of the UN Climate Security Mechanism is also recognized by S-Africa, and even highlighted as requiring support by Indonesia (UNSC, 2020, p. 23).

Comparing these concerns to the proposed climatesecurity concept, I conclude that the seemingly divergent and partly opposing positions of the 2020 UNSC member states do in fact passively share a certain climate-security conception. The first column of Table 2 presents the clusters of concern and in the second column shows how the re-formulation of these concerns intersects with the proponents' views on climate-security nexus.

Thus, a certain agreement on the climate-security concept exists within the UNSC 2020. This analysis showed the beneficial effects that the effort to disentangle the climate-security cocktail into more specific arguments has in terms of opening up possibilities for dialogue. These research results raise new questions concerning future developments, which I will outline in the following section.

\subsection{Projections, Evaluations, and Implications: Rising to the Challenge of the Anthropocene?}

The research findings of an existing overlap on the climate-security nexus concept among all 15 UNSC member states in 2020 suggest that (overriding possible underlying power politics, national interests, and value considerations), on the basis of dialogue and diplomatic efforts, an official adoption of climate change in the UNSC seems forthcoming. While it is important to note that the above-described intersections applied to the UNSC-member states of 2020 and that the UNSC member states constellation is different now, the climatesecurity nexus remains on the agenda also in 2021. Thus, another UNSC debate on the issue was initiated by the UK in February 2021, and the new US administration explicitly affirms that "the climate crisis is indisputably a Security Council issue" (PM US, 2021). Also, the recent creation of an Informal Expert Group on Climate and Security tolerated by Russia and China-both send observers to the meetings (Security Council Report, 2021) - further suggests an at least passive acknowledgement of the climate-security nexus.

The prospect of an adoption of climate change can be evaluated as a sign that the UNSC takes this issue 
Table 2. Comparison of descriptions on climate-security nexus at the UNSC 2020.

Clusters of concerns of sceptics of including climate change in the UNSC

- UNFCCC and the Paris Agreement are the bodies in charge of climate change

- Different mandates, available resources and expertise of the UNFCCC and the UNSC should not overlap

- Scientific evidence on the generalized links between climate change and conflict is missing

- Conflict constellations and causes are country- or region-specific

- Root causes of conflicts are complex, even if climate change might be one of the factors
Overlaps between the proponents and sceptics on climate-security nexus

- UNFCCC is the primary mandate for handling climate politics

- Duplications of mandates need to be avoided

- Additional scientific evidence on climate-security nexus is required and a de-politicized analysis to be avoided

- Climate change in certain regions affects security, via being linked to conflict and weather extremes and is therefore context-specific

Sources: PM Russia (2020); PM US (2020); UNSC (2020); and also Table 1.

seriously and as a symbolically important step that realizes a long-term goal both in practice (since the first debate in 2007) and in theory (see e.g., Scott \& Ku, 2018). I do, however, evaluate this potential recognition as but a minor change in relation to the UNSC itself and to the meaning of security more generally. This is for the following reasons. First, the climate-security conceptions cover certain topics that are relatively congruent with the traditional security concept, in the sense of being limited to conflict, especially in specific and vulnerable regions. The underlying understanding of the object of security and of security (conflict and stability), as well as the UNSC mandate, remain untouched. Moreover, several recognitions of the climate-security nexus that are already in place, e.g., in the UNSC Resolutions (see e.g., UNSC, 2017, for Resolution 2349 on Niger; for various field mission mandates, see e.g., MINUSMA [Mali]; MINUSCA [CentralAfrican Republic]; UNOWAS [Sahel]; UNAMID [Darfur]), refer to the relation between climate change and stability. In January 2021, two additional UNSC Resolutions that include climate change were agreed upon, which for the first time widen the geographical scope beyond the African continent to include Cyprus and Iraq (Security Council Report, 2021). It could therefore be argued that climate change has entered the UNSC through a back door, that it is already part of the central UNSC instruments (see Maertens, 2021), and that, as a result, an official recognition would have little effect beyond an a posteriori endorsement.

If compared to the scientific descriptions of existential threats in the Anthropocene, the effects of such a limited inclusion of the climate-security nexus in the UNSC would be relatively insignificant, in the sense that it ignores the most crucial concerns. As shown by Maertens and Hardt (2021, p. 53), "the term 'Anthropocene' does not appear in UN Security Council documents and debates." The new meanings and qualitative shifts for a security understanding of the human natureentangled dynamic world of the Anthropocene is totally eclipsed. Even though the above-described statements from Germany and SVG (UNSC, 2020, pp. 13, 25) allude to broader conceptions of nature, they still rely on the Holocene understanding of nature as a counter-force from which humans are detached and against which a unified fight is necessary. Similarly, China's (UNSC, 2020, p. 17) statement highlights that:

Humans and nature share a community of life. What hurts nature hurts humans. Climate change poses a major obstacle to sustainable development. The outbreak of the coronavirus disease (Covid-19) reminds us again that no country or individual is immune to global challenges, and solidarity and cooperation are what is most needed. Climate change endangers the future of humankind and requires joint efforts by all of us.

The socio-ecological intertwinements of the Anthropocene and the scientific predictions of the Earth System Sciences concerning trajectories towards a Hothouse Earth (Lenton et al., 2019; Steffen et al., 2018) and the existential threat for future generations have apparently not yet entered the understanding of the existing climate-security nexus at the UNSC level (Hardt \& Viehoff, 2020, pp. 108-110). In general, and despite the reference to the need to "drastically change our planet's trajectory" (UNSC, 2020, p. 25 [SVG]), socio-ecological intertwinements are not considered, or only in the sense of a cause-and-effect chain that impacts on humans, stability, and security (conflict). Further descriptions on the matter of ecology, such as, e.g., possible "tipping cascades," which cause "abrupt, nonlinear responses (conversion of Amazon to Savanna)" (Lenton et al., 2019; Steffen et al., 2018, p. 4) and uncontrollable change, or any other additional temporally extensive security threat related to climate change remain absent. At the same time, it is significant that this approach to include climate change into the UNSC singles the UNFCCC out as the primary body of 
intervention with respect to addressing the root causes of climate change. This is how one of the effects would turn the UNFCCC into a security actor via reducing the likelihood for conflict and at the same time put it in charge of handling existential threats.

\section{Concluding Remarks and Outlook}

This article addressed the following questions: a) is an official recognition of a link between climate change and security in the UNSC likely in the near future?; b) what does the proposition to include climate-security in the UNSC look like?; c) what would this imply for the UNSC as an institution?; and d) how does this approach measure up to the scientific descriptions of climate threats and Anthropocene contexts? The analysis produced three main insights. First, I exposed the climate-security concept. Second, I showed that, in contrast to previous expectations, a certain passively shared mainstream conception of an interrelated climate-security nexus exists. I conclude that, as a result, a consensus on the matter is being established, which also produces incoherences and confusions. Third, however, a transformative change of the UNSC and of the meaning and politics of security is not in sight; on the contrary, the basic tenets of international relations in force since 1945 persist despite the new challenges and threats described by the sciences.

Comparing these research results to existing Security Studies literature on the climate-security nexus can help formulate a range of future research questions. First, Security Studies and climate change research will have to re-assess several key assumptions and also specifically focus on the theory-practice analysis. Doubts on whether the concept of security changes need to be re-assessed in light of analyzing the practices by several actors (see also Berling et al., 2021). Another research finding is that a frequently mentioned counter-argument against the climate-security nexus, namely a possible militarization of the issue (see Trombetta, 2008), is not mentioned by the opponents (see Section 3). In the UNSC 2020 debate, possible militarization was only mentioned once for the case of the Arctic-and not as a possible adverse impact but as an already occurring phenomenon (UNSC, 2020, p. 10 [Belgium]), so in terms of a pro-argument. Future research will have to examine more systematically the climate-security concept analyzed here in light of scientific research on the climatesecurity link. As I have outlined above, this concept excludes and ignores important scientific descriptions of climate security. Another future research inquiry could focus on why, e.g., the Anthropocene and the scientific descriptions from the Earth System Sciences are not taken up at the UNSC debates. The reasons for this still need to be analyzed, and one possible research path could follow the lines of information flow and the relatively non-transparent science-policy nexus. Assessing the sources and providers of knowledge on climatesecurity links would require an analysis of the role of think tanks-for example, the think tank Adelphi, which is explicitly mentioned in the UNSC debate (UNSC, 2020, pp. 5-6 [Niger])-as well as other experts who contribute to the discussion. Aside from the power politics of knowledge, other forms of power politics within the climate-security nexus require more attention from researchers. Finally, another important research question should more specifically concern uncovering the institutional gap in the UN system that exists with respect to the existential security threats in the context of the Anthropocene and engage more specifically in how to break this stalemate.

Overall, the analysis presented here attempted to disentangle the climate-security black box by investigating the prevalent understandings of this nexus aiming to open up opportunities for future dialogue and also for drawing out what remains to be addressed. It aimed to encourage additional efforts to think security in the Anthropocene, as the existential security threats (see Sears, 2020) and new meanings of security as yet remain largely ignored by the only institution that has the mandate to deal with security threats.

\section{Acknowledgments}

I thank the two anonymous reviewers, Olaf Corry, Adrien Estève, Lucile Maertens, and Julia Maria Trombetta for their constructive criticism. This research partly draws on the project Climate Change and Security in the United Nations Security Council (2019-2020) and was funded by the German Federal Ministry of Education and Research in the context of the research project Multiple Crises: Covid-19 and the Entanglements of Public Health, Security and Ecology in Europe (2021-2024) associated with the CMB.

\section{Conflict of Interests}

The author declares no conflict of interests.

\section{References}

Barkin, M. (2020). Remarks at a UN Security Council Arriaformula meeting on climate change and security risks (via VTC). https://usun.usmission.gov/remarksat-a-un-security-council-arria-formula-meeting-onclimate-change-and-security-risks-via-vtc

Barnett, J., \& Adger, N. W. (2007). Climate change, human security and violent conflict. Political Geography, 26(6), 639-655.

Berling, T. V., Gad, U. P., Petersen, K. L., \& Wæver, O. (2021). Translations of security: A framework for the study of unwanted futures. Routledge.

Bigo, D. (2010). International political sociology. In P. D. Williams (Ed.), Security studies. An introduction (pp. 116-129). Routledge.

Booth, K. (2005). Critical security studies and world politics. Lynne Rienner Publishers. 
Burke, A., Lee-Koo, K., \& McDonald, M. (2014). Ethics and global security. A cosmopolitan approach. Routledge.

Buzan, B., Wæver, O., \& De Wilde, J. (1998). Security: A new framework for analysis. Lynne Rienner Publishers.

Conca, K. (2019). Is there a role for the UN Security Council on climate change? Environment: Science and Policy for Sustainable Development, 61(1), 4-15.

Corry, O. (2012). Securitisation and 'riskification': Second-order security and the politics of climate change. Millennium, 40(2), 235-258.

Cousins, S. (2013). UN Security Council: Playing a role in the international climate change regime? Global Change, Peace \& Security, 25(2), 191-210.

Cudworth, E., \& Hobden, S. (2011). Posthuman international relations: Complexity, ecologism, and global politics. Zed Books.

Dalby, S. (2020). Anthropocene geopolitics: Globalization, security, sustainability. University of Ottawa Press.

Dziadosz, A. (2020, July 24). US halts German Security Council push for UN climate conflict monitoring. Clean Energy Wire. https://www.cleanenergywire. org/news/us-halts-german-security-council-pushun-climate-conflict-monitoring

Estève, A. (2021). Preparing the French military to a warming world: Climatization through riskification. International Politics, 58, 600-618.

Fillion, S. (2021, February 18). Can the issue of climateinduced wars stick to the UN Security Council agenda? The UK tries it out. PassBlue. https://www. passblue.com/2021/02/18/can-the-issue-of-climateinduced-wars-stick-to-the-un-security-councilagenda-the-uk-tries-it-out

Hardt, J. N. (2018). Environmental security in the Anthropocene: Assessing theory and practice. Routledge.

Hardt, J. N. (2021). Trajectories towards the existential. Encounters with earth system sciences: Planetary boundaries and hothouse earth. In D. Chandler, F. Müller, \& D. Rothe (Eds.), International relations in the Anthropocene: New actors, new agencies and new approaches (pp. 39-54). Palgrave McMillan.

Hardt, J. N., \& Viehoff, A. (2020). A climate for change in the UNSC? Member states' approaches to the climate-security nexus (Research Report \#005). Institute for Peace Research and Security Policy. https:// ifsh.de/en/publications/research-report/researchreport-005

Harrington, C., \& Shearing, C. (2017). Security in the Anthropocene. Reflections on safety and care. Transcript Verlag.

IPCC. (2021). Climate change 2021: The physical science basis (Working Group I contribution to the Sixth Assessment Report). Cambridge University Press.

Lenton, T. M., Rockström, J., Gaffney, O., Rahmstorf, S., Richardson, K., Steffen, W., \& Schellnhuber, H. J. (2019). Climate tipping points-Too risky to bet against. Nature, 575(28), 592-595.

Lövbrand, E., Mobjörk, M., \& Söder, R. (Eds.). (2021).
Anthropocene securities: Recollections and reflections 50 years after the Stockholm conference on the human environment. MIT Press.

Mach, K. J., \& Kraan, C. (2021). Science-policy dimensions of research on climate change and conflict. Journal of Peace Research, 58(1), 168-176.

Maertens, L. (2021). Climatizating the UN Security Council. International Politics, 58, 640-660.

Maertens, L., \& Hardt, J. N. (2021). Climate change and security within the United Nations: Insights from the UNEP and the UNSC. In E. Lövbrand, M. Mobjörk, \& R. Söder (Eds.), Anthropocene securities: Recollections and reflections 50 years after the Stockholm conference on the human environment. MIT Press.

McDonald, M. (2018). Climate change and security: Towards ecological security? International Theory, 10(2), 153-180.

Mearsheimer, J. J. (2001). The tragedy of great power politics. W. W. Norton.

Peoples, C., \& Vaughan-Williams, N. (2010). Critical security. An introduction. Routledge.

PM Russia. (2020). Statement by Vassily Nebenzia, Permanent Representative of Russia to the UN, at the VTC of UNSC members "Climate and Security". https://russiaun.ru/en/news/climate_240720

PM US. (2020). Remarks at a UN Security Council open debate on climate and security (via VTC). https:// usun.usmission.gov/remarks-at-a-un-securitycouncil-open-debate-on-climate-and-security-viavtc

PM US. (2021). Remarks at a UN Security Council open debate on climate and security (via VTC). https:// usun.usmission.gov/remarks-at-a-un-securitycouncil-open-debate-on-climate-and-security-viavtc-2

Rockström, J., Steffen, W., Noone, K., Persson, Å., Chapin III, F. S., Lambin, E., Lenton, T. M., Scheffer, M., Folke, C., Schellnhuber, H. J., Nykvist, B., de Wit, C. A. Hughes, T., van der Leeuw, S., Rodhe, H., Sörlin, S. Snyder, P. K., Costanza, R., Svedin, U., . . . Foley, J. (2009). Planetary boundaries: Exploring the safe operating space for humanity. Ecology and Society, 14(2), Article 32.

Scott, S. (2015). Implications of climate change for the UN Security Council: Mapping the range of potential policy responses. International Affairs, 92(6), 1317-1334.

Scott, S., \& Ku, C. (Eds.). (2018). Climate change and the UN Security Council. Edward Elgar Publishing.

Sears, N. A. (2020). Existential security: Towards a security framework for the survival of humanity. Global Policy, 11(2), 255-266.

Security Council Report. (2021). The UN Security Council and climate change. https://www.securitycouncil report.org/atf/cf/\%7B65BFCF9B-6D27-4E9C-8CD3CF6E4FF96FF9\%7D/climate_security_2021.pdf

Steffen, W., Rockström, J., Richardson, K., Lenton, T. M., Folke, C., Liverman, D., Summerhayes, C. P., 
Barnosky, A. D., Cornell, S. E., Crucifix, M., Donges, J. F., Fetzer, I., Lade, S. J., Scheffer, M., Winkelmann, R., \& Schellnhuber, H. J. (2018). Trajectories of the earth system in the Anthropocene. Proceedings of the Natural Academy of Sciences of the United States of America, 115(33), 8252-8259.

Swain, A., \& Öjendal, J. (Eds.). (2018). Routledge handbook of environmental conflict and peacebuilding. Routledge.

Ten UNSC Member States. (2020, June 22). Joint statement by 10 members of the UN Security Council on their joint initiative to address climate-related security risks [Press release]. https://new-york-un.diplo. de/un-en/news-corner/200622-climate/2355076

Trombetta, J. (2008). Environmental security and climate change: Analysing the discourse. Cambridge Review of International Affairs, 21(4), 585-602.

Trombetta, J. (Ed.). (in press). Handbook of climate change and international security. Edward Elgar.

United Nations General Assembly. (2009a). General Assembly sixty-third session. 85th plenary meeting
(A/63/PV.85). https://undocs.org/en/A/63/PV.85

United Nations General Assembly. (2009b). Climate change and its possible security implications. Report of the Secretary-General (A/64/350). https://www. un.org/ga/search/view_doc.asp?symbol=A/64/350

United Nations General Assembly. (2009c). Climate change and its possible security implications. Resolution adopted by the General Assembly (A/RES/ 63/281). https://www.securitycouncilreport.org/atf/ cf/\%7B65BFCF9B-6D27-4E9C-8CD3-CF6E4FF96FF9\% 7D/res\%2063\%20281.pdf

UNSC. (2011). Statement by the President of the Security Council (S/PRST/2011/15). https://undocs.org/S/ PRST/2011/15

UNSC. (2017). Resolution 2349 (S/RES/2349). https:// undocs.org/S/RES/2349(2017)

UNSC. (2020). Letter dated 28 July 2020 from the President of the Security Council addressed to the Secretary-General and the Permanent Representatives of the members of the Security Council (S/2020/ 751). https://undocs.org/S/2020/751

\section{About the Author}

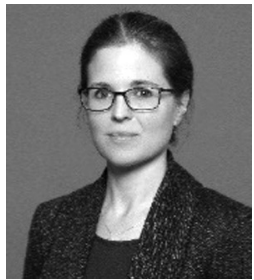

Judith Nora Hardt (PhD) is a postdoctoral researcher at the Franco-German Research Centre for Social Sciences Centre Marc Bloch (An-Institut Humboldt University, Berlin), and principal researcher of the Multiple Crises project. She is associated to the Institute for Peace Research and Security Policy (Hamburg University), is part of the research group Climate Change and Security at the University of Hamburg, and is active in the Network of Scientists For Future. 